\title{
Three Principles for Market-based Credit Regulation
}

\author{
Perry Mehrling \\ Barnard College, Columbia University
}

December 31, 2011

Prepared for American Economic Association meeting, Chicago, January 7, 2012. I would like to thank Aaron Brown, Tom Michl, Daniel Neilson, and Zoltan Pozsar for especially useful comments on an early draft, as well as participants in seminars at the Brookings Institution, Boston University, Credit Suisse, Fondation des Treilles, and the International Monetary Fund. 
Over the last three decades, a new market-based credit system has grown up to become larger than the traditional bank-based credit system, marking that achievement in 2007 with a financial crisis of its very own. ${ }^{1}$ Some say the crisis was a "Minsky moment" when the inherent instability of credit-market-based credit as well as bank-based credit--was revealed for all to see. While not necessarily disagreeing with that formulation, I prefer to emphasize that it was a "Bagehot moment" when the Fed was forced to put aside its inflation fine-tuning and go back to basics. In retrospect, it was the actions of the Fed, more than anything else, that put a floor on the crisis. The Fed did this by catching collapsing markets on its own balance sheet, first the wholesale money market and then the mortgage-backed security market. ${ }^{2}$ The question now arises how to avoid ever having to do so again.

\section{Back to Basics}

The seminal importance of Bagehot's Lombard Street (1873) for shaping how we think about these matters is agreed by all. The Bagehot Rule for handling financial crisis--"lend freely but at a high rate" -was Bagehot's attempt to distill the principles of central bank practice as that practice had developed organically over the previous fifty years. Today the Bagehot Rule is where everyone starts when thinking about the role of the central bank, even if most of the subsequent discussion is about how to avoid crisis in the first place: microprudential policy, stabilization policy, and now perhaps macroprudential policy.

My concern about this near-universal framing of the problem is that the world Bagehot was thinking about is, in crucial respects, not the world we are dealing with today. Bagehot was all about the $19^{\text {th }}$ century money market; our new market-based credit system is about the $21^{\text {st }}$ century integration of

\footnotetext{
${ }^{1}$ I follow Pozsar (2011) in preferring the term "market-based credit system" over "shadow banking system".

${ }^{2}$ Although my own account of the crisis focuses on the Fed (Mehrling 2011), a rounded understanding of government response requires at a minimum also understanding the roles of the Treasury (Swagel 2009), the Federal Home Loan Bank (Ferguson and Johnson 2009), the Congress (FCIC 2010, SIGTARP 2010), and even the global dollar funding system (McGuire and von Peter 2009). In academic circles, Brunnermeier (2009), Gorton (2010), and Krishnamurthy (2010) have become standard accounts.
} 
the money market with the capital market. As a consequence, when the Fed went back to basics, it found that it had to go beyond Bagehot.

Starting in August 2007, the Fed's first strategy for handling the crisis was simply to lower the Fed Funds rate, from $5 \%$ to $2 \%$, i.e. standard, albeit aggressive, monetary easing. It wasn't enough. Then, after the collapse of Bear Stearns in March 2008, the Fed embarked on a massive program of Bagehot-style last-resort lending, liquidating much of its customary holdings of Treasury bills and bonds and lending out the proceeds, not only to banks but also to broker-dealers. But that wasn't enough either.

After the collapse of Lehman Brothers in September 2008, and while the attention of most of the world was focused elsewhere, the Fed expanded its balance sheet on both sides, offering itself as counterparty to both sides of a wholesale (and global) money market that had frozen up. And then in March 2009, as the money market had begun to recover, the Fed went even further, replacing its money market lending with outright purchases of mortgage-backed securities, almost $\$ 1$ trillion worth added to a balance sheet that had been less than $\$ 1$ trillion only six months before.

One lesson to draw from this experience is that, in modern conditions, the central bank serves not merely as Bagehot-style lender of last resort but even more as "dealer of last resort". After Lehman, in effect the Fed quoted a price at which it was willing to buy money and a price at which it was willing to sell money, and then absorbed the resulting order flow onto its own balance sheet. That's what dealers do (Treynor 1987, Harris 2003). In modern finance theory, liquidity means the ability to buy or sell, in size, without moving the price. In normal times, dealers supply this liquidity (make markets) by offering trading options. ${ }^{3}$ During the crisis, this normal supply broke down, and the Fed stepped in to fill the gap.

\footnotetext{
${ }^{3}$ In normal times, the so-called "channel system" for monetary policy implementation (Bindseil 2005) establishes a public dealer "outside spread" around the prevailing "inside spread" established in private dealer markets. See Mehrling (2010).
} 
In doing so, the Fed clearly went beyond the intentions of its century-old founders. ${ }^{4}$ The mental world of the founders was much more that of Bagehot, not the world of today; indeed they envisioned a Fed confined entirely to the discount of commercial bills! However, the exigencies of war finance soon forced widening of their mental horizons, as the new Fed instead started life by providing backstop for the sale of Treasury debt. Subsequently, Depression and the Second World War further cemented the centrality of Treasury debt markets in the U.S. financial system. When life finally settled down, the Fed adapted to changed circumstances by conducting its operations primarily in those debt markets (FOMC 1952). In wartime, the Fed had acted as primary dealer for government debt; in peacetime, it handed that role over to private security dealers.

The familiar distinction between market liquidity and funding liquidity (Brunnermeier and Pedersen 2009) is useful for understanding the difference between central banking in wartime and in peacetime. ${ }^{5}$ In peacetime, private dealers supply market liquidity by quoting two-way markets, but their ability to absorb the resulting order flow depends on their access to funding liquidity, specifically their access to bank lending. In peacetime, therefore, central banks quite properly focus their attention largely on funding liquidity, and on banks as suppliers of that funding liquidity, depending on private dealers for reliable transmission of monetary intervention to the wider capital market. Under the stress of wartime, however, the dealer transmission mechanism breaks down, so central banks take over the job of supplying market liquidity (dealer of last resort) as well as funding liquidity (lender of last resort).

The key point is that what happened in the crisis of 2007 was analogous to what happens in wartime. "Dealer of last resort" was not new; what was new was the extension of dealer of last resort from government securities to private mortgage-backed securities.

\footnotetext{
${ }^{4}$ To avoid misunderstanding, I do not mean to suggest that the Fed did anything illegal. In my mind, there is no question that the Fed was faced with the "unusual and exigent circumstances" necessary to invoke the special powers of Section 13(3).

${ }^{5}$ This distinction can be understood as a modern version of Moulton's (1918) distinction between "shiftability" (or saleability) and "self-liquidation".
} 
The reason this extension became necessary is not hard to find; it was a consequence of the rising importance of market-based credit. In a bank-based credit system, funding liquidity and lender of last resort is enough to ensure the continued flow of credit. A market-based credit system, however, relies on market liquidity and hence ultimately on dealer of last resort to ensure the continued flow of credit. Just as the Fed adapted, in its first fifty years, to the rise of a market-based system of government credit, the Fed's present task is to adapt to the rise of a market-based system of private credit. The Fed's shifting role during the crisis can be understood as the first steps toward that adaptation.

While some few voices did warn of an unsustainable credit bubble before 2007 , almost no one anticipated that the collapse of the bubble would play out the way it did. Indeed, the market-based credit system was widely supposed to be a way of taking risk off the balance sheet of banks, hence also off the balance sheets of the FDIC (deposit guarantee) and the Fed (liquidity guarantee). By moving risk into the capital market, bank deposits were supposed to be kept safe. By moving risk into the global financial system, the domestic financial system was supposed to be kept safe.

But when money markets refused to roll their funding for the market-based credit system, liquidity backstops in the traditional banking system got triggered, and as a result risk moved back on to the balance sheets of banks. And when the problem proved too big for them to handle, the ultimate liquidity backstop at the Fed got triggered as well. Contrary to expectation, the collapse of a capital market credit bubble wound up threatening the safety and soundness of the traditional banking system and so, again contrary to expectation, wound up on the balance sheet of the government.

In the aftermath, politicians have said "Never Again!", and Dodd-Frank (as well as Basel III) is supposed to make sure of it, mainly with enhanced capital and liquidity requirements designed to bolster the safety and soundness of the traditional banking system. Such measures largely ignore the market-based credit system, even as they seem likely to ensure that the prohibited activities will move 
outside the traditional banking system, which is to say into a newly revived market-based credit system.

The big challenge for regulation looking forward is therefore to grapple with that new system.

\section{A Model of Market-Based Credit}

What system of regulation would make sense if the market-based credit system were more or less completely to replace the bank-based credit system?

To help in thinking about this question, Figure 1 shows a stylized picture of a market-based credit system. To avoid misunderstanding, the figure it is not intended to be a map of the shadow banking system circa 2007, nor even a stylized picture of that system (see Pozsar et al 2010 for the former, Mehrling 2011 Ch. 6 for the latter). The shadow banking system was certainly a kind of marketbased credit system, but it was hardly fully developed and it was very much shaped by the traditional banking system context within which it grew up. Furthermore, as a consequence of the crisis, many of the key innovations of the shadow banking system are now gone forever, having failed to survive their first major stress test. The shadow banking system as we knew it is thus gone, but the larger trend toward a market-based credit system continues.

[Insert Figure 1 about here]

The Figure shows not so much what the shadow banking system actually looked like, but rather what a possible market-based credit system might look like in the future. ${ }^{6}$ Instead of the complicated

\footnotetext{
${ }^{6}$ To avoid misunderstanding, the Figure is not intended to be a map of an entire possible future market-based credit system, only the portion that is critical for the discussion that follows. Thus, I abstract on the one hand from the familiar capital market in which long-term borrowers issue securities that are acquired by long-term investors, i.e. the province of standard financial economics. And I abstract on the other hand from the familiar money market, where banks and non-banks issue deposits and deposit substitutes to households and non-financial corporations who seek money balances on one of the standard motives, i.e. the province of standard monetary
} 
tranching of the actual shadow banking system, which served to strip risk out of the underlying mortgage loans, I'm imagining a future "Capital Funding Bank" in which all the risk stripping is done using simple derivatives, Interest Rate Swaps and Credit Default Swaps. And instead of the complicated system of capital buffers involving credit derivatives sold to hedge funds and insurance companies, I'm imagining that all of the risk is transferred to an "Asset Manager" who uses simple derivatives in order to achieve his desired risk exposure. The "Capital Funding Bank" is thus the mirror image of the "Asset Manager" not only in terms of funding but also in terms of risk. CFB funding liabilities are the counterpart of AM assets, and AM liabilities (derivatives) are the counterpart of CFB assets.

In this system, two different financial intermediaries are crucial. ${ }^{7}$ First is the Global Money Dealer that takes care of the funding transfer, in effect mobilizing the customer capital held by the Asset Manager to fund the Residential Mortgage-Backed Securities held by the Capital Funding Bank. The second is the Derivatives Dealer that takes care of the risk transfer, in effect mobilizing the risk capacity of the customer capital to bear the risk in the RMBS. (Note that I adopt the accounting convention of treating derivatives as contingent liabilities of the agent bearing the risk; since funding markets are short term, long term fixed rate assets are risky.)

It should be emphasized that, by construction, both intermediaries are pure dealers holding completely "matched book" and taking no net risky positions of their own. (They are Volcker-Rule dealers, idealized pure market makers that do no proprietary trading.) The Global Money Dealers quote buy and sell prices for money, while the derivative dealers quote buy and sell prices for term and credit

economics. My starting point instead is the place where the capital market and money market intersect, i.e. the province of the intersection between financial economics and monetary economics.

${ }^{7}$ My emphasis on the dealer function follows Hicks (1989), but see also Shaw (1950, p. 9) and Stigum and Crescenzi (2007) who conceptualize banks as a specialized kind of security dealer. The secured deposits supplied by the GMD are clearly different in kind from the bank deposits of standard monetary economics, as also the collateral demand for those deposits coming from the Asset Manager. The idea of a Global Money Dealer focused on funding transfer was inspired by the account of cross-border banking offered by Shin and Shin (2011). The idea of a Derivatives Dealer focused on risk transfer was inspired by the account offered by BIS (2008). 
spreads. Through arbitrage, the price of the underlying risky asset (RMBS) is implied by these dealer prices, and vice versa.

In this market-based credit system, counterparty risk is handled by using collateral; all positions are fully secured. Specifically, by some system of hypothecation and rehypothecation, RMBS collateral flows to the Global Money Dealer to support money market funding, and then flows further to the Asset Manager as security for his deposit. ${ }^{8}$ Similarly, all derivatives exposures are secured by pre-funding of a kind; the AM's deposit at the GMD is sufficient to cover any losses from its derivative liabilities, and the CFB's RMBS holding is sufficient to cover any losses from its derivative assets.

The purpose of this conceptualization is to abstract from solvency issues, and hence also from all questions of capital adequacy. By construction, any valuation change in the ultimate risky assets held by the Capital Funding Bank is matched by a valuation change in the customer capital that funds the Asset Manager. In this stylized model, customer capital is the risk capital for the entire system; there is no need for separate capitalization of the Capital Funding Bank, the Global Money Dealer, or the Derivatives Dealer, since by construction all asset risk is transferred to the Asset Manager.

The purpose of thus abstracting from all solvency risk is to focus attention instead on liquidity risk, and specifically on the role of the dealers in bearing that risk, and on the central bank as backstop for those dealers. Suppose, for example, that the value of the RMBS falls by $\$ 10$. Now the CFB has a funding problem, since its posted RMBS collateral is no longer sufficient to support its borrowing from the GMD. At the same time, the $A M \prime s$ derivative liability increases by $\$ 10$, requiring it to post increased deposit collateral to the Derivative Dealer. What is apparently required to make the market-based credit system work is a mechanism for shifting the AM's deposit collateral to the credit of the CFB in such a way as to make that collateral available to support continued borrowing from the GMD.

\footnotetext{
${ }^{8}$ This way of thinking about secured lending was inspired by the account of Singh and Aitken (2010).
} 
The way this plays out in balance sheets is shown in Figure 2a; note the credit expansion on the balance sheet of the Derivative Dealer, a credit expansion that is secured by the aforementioned transfer of collateral. If the valuation change is temporary then, when value returns to its previous level, collateral will flow back in the opposite direction and the credit expansion will be cancelled. But if the valuation change is permanent, then at some point losses are realized by actual payment, as shown in Figure $2 \mathrm{~b}$. The Asset Manager pays $\$ 10$ to the Derivative Dealer, who then pays the CFB, who then uses the payment to reduce borrowing from the GMD. The net effect is a credit contraction on the balance sheet of the Global Money Dealer, as money market funding contracts to the size of the underlying capital value being funded.

[Insert Figures $2 \mathrm{a}$ and $2 \mathrm{~b}$ about here]

In either case, $2 \mathrm{a}$ or $2 \mathrm{~b}$, the important point to emphasize is that the mechanism through which fluctuation in the value of risky assets is absorbed by customer capital involves fluctuation in the size of dealer balance sheets. And the mechanism that produces balance sheet fluctuation is the flow of collateral and money payments. In Figures $2 \mathrm{a}$ and $2 \mathrm{~b}$, the payments system is assumed to operate perfectly. But if it does not, there is clearly a lot of room for self-reinforcing liquidity spirals (as Brunnermeier 2009).

For example, if for any reason the CFB were unable to top up the collateral for its money market borrowing, it might be forced to liquidate some portion of its assets, so driving down their price even more and worsening its own funding problem. Further, if it fails to receive additional collateral from the CFB, the GMD would be unable to top up the collateral needed to support its own secured deposit liabilities, and so might face a funding problem of its own. By construction, these are liquidity problems, not solvency problems, hence the province of a central bank. 
Alternatively, if for any reason the Asset Manager were unable (or even merely unwilling) to post collateral for its derivative liability, the Derivative Dealer might be forced to close out the Asset Manager's position, driving derivative "insurance" prices up and hence the implied RMBS price down even more, so worsening the problem. Further, without additional collateral from the Asset Manager, the Derivative Dealer will be unable to top up the collateral needed to support its derivative liability to the CFB, and so might face a margin call of its own. Again by construction, these are liquidity problems, not solvency problems, hence the province of the central bank.

Lender of last resort is one response to these problems. The central bank could lend to the Global Money Dealer, so directly backstopping the liquidity of its deposit liabilities to the Asset Manager while also indirectly supporting continued lending to the CFB. And if that is not enough, the central bank could also lend to the Derivative Dealer, so directly backstopping the liquidity of its derivative liabilities to the CFB while also indirectly supporting continued forbearance on collateral margin calls to the Asset Manager.

But the focus on funding dealers may not be enough to stop the rout. Nothing in lender of last resort prevents the Global Money Dealer from demanding additional collateral from the CFB anyway, not only to cover current mark-to-market losses but also, even more, as safeguard against possible future losses. (Increased "haircuts" on RMBS collateral is one way to do this. ${ }^{9}$ ) And nothing in lender of last resort prevents the Derivative Dealer from demanding additional collateral from the Asset Manager anyway, not only to cover current mark-to-market losses on derivative positions but also, even more, as safeguard against possible future losses. And nothing prevents the CFB or the Asset Manager from

\footnotetext{
${ }^{9}$ Gorton and Metrick (2010) view this haircut dynamic alternatively as the shadow banking analogue of a classic bank run.
} 
responding to this pressure by attempting to liquidate their positions, so continuing the downward liquidity spiral. $^{10}$

The key point is that, in a market-based credit system where all funding is secured by collateral, the value of collateral plays a much more crucial role than in a bank-based credit system. In such a system, therefore, a central bank liquidity backstop may need to embrace also dealer of last resort by bidding, in the open market, for some subset of the risky assets that are serving as collateral. The central bank could bid directly for RMBS, so directly supporting the value of CFB collateral, and indirectly the value of Asset Manager derivative positions. Or it could offer directly for RMBS derivatives, so directly supporting Asset Manager positions, and indirectly supporting the value of CFB collateral. Or it could do a bit of both, so directly backstopping market liquidity in both derivative markets and the underlying cash markets.

The point of such intervention, it is important to emphasize, is not so much to take assets (or risk) off the market but rather to prevent a liquidity spiral from destabilizing the price of those assets and so, as a consequence, undermining their use as collateral in the market-based credit system. As with the Bagehot Rule, much of the impact of such intervention comes not from the actual positions taken by the central bank but rather from the price support provided by trading options that may well remain unexercised and so never show up on the central bank's balance sheet.

By way of summary, here are three principles that seem to follow from this way of thinking:

1. Asset markets, not banking institutions; market liquidity, not funding liquidity; dealer of last resort, not lender of last resort. This most important first principle reminds that market liquidity is the more relevant concept for a market-based credit system, that market liquidity is normally supplied by

\footnotetext{
${ }^{10}$ And of course nothing prevents that downward spiral from spilling over to the larger financial system, from

which we have been abstracting. See footnote 4.
} 
dealers, and that the best way to support the dealer system in a crisis may be to support the markets in which they deal by supporting key collateral values.

2. Outside spread, not inside spread. Bagehot's Rule for funding liquidity emphasizes lending freely but at a high price, the high price being his safeguard against what modern economists would call moral hazard; only those in true need will borrow, and they will pay back as soon as they are able. Analogously, a modern central bank rule for market liquidity should emphasize buying and selling freely but at a wide spread around what price would be in more normal times.

3. Core assets, not periphery. Bagehot emphasized lending against "all good banking securities" which he specifies as "what in ordinary times is reckoned a good security-on what is then commonly pledged and easily convertible." Note that Bagehot speaks of ordinary times, not crisis times, but also not boom times. It is not the job of the central bank to make bad securities good, but only to stop a liquidity spiral; it can do this most efficaciously by focusing its liquidity support operations on a subset of good securities (rather than a subset of too-big-to-fail banks).

\section{Conclusion}

The crisis of 2007-2008 was a Bagehot moment, when the brave new world of market-based credit suffered its first stress test, and the Fed had to go back to basics to find an adequate response. What it found, and what I have labeled "dealer of last resort", can be understood as a natural extension of Bagehot-style lender of last resort for the new market-based credit system. The transformation of the Fed's balance sheet, shown in the first two panels of Figure 3, brings out how much has changed. The size of the balance sheet has tripled, but also its composition has changed.

The restatement of its current balance sheet in the third panel is intended to make clearer the dimensions of the Fed's dealer-of-last-resort intervention, dimensions that remain on its balance sheet even today. By adding short-term T-bill holding and long-term T-bond holdings to both sides of the 
balance sheet, and rearranging, three fundamental risk exposures can be distinguished: a kind of overnight index swap (first line), a kind of interest rate swap (second line), and a kind of credit default swap (third line). In all three dimensions, the Fed is operating to support market liquidity, much as our idealized Global Money Dealer and Derivative Dealer do on their balance sheets. In all three dimensions, the Fed can be seen as adapting to its new role as liquidity backstop for the emerging new market-based credit system.

[Insert Figure 3 about here] 
Figure 1: A Stylized Market-Based Credit System

\begin{tabular}{|c|c|c|c|c|c|c|c|}
\hline \multicolumn{3}{|c|}{ Capital Funding Bank } & \multicolumn{2}{|c|}{ Global Money Dealer } & \multicolumn{3}{|c|}{ Asset Manager } \\
\hline Assets & & Liabilities & Assets & Liabilities & Assets & Liabilit & \\
\hline RMBS & 100 & MM funding 100 & MM funding 100 & "deposits" 100 & "deposits" 100 & Capital & 100 \\
\hline CDS & 0 & & & & & CDS & 0 \\
\hline IRS & 0 & & & & & IRS & 0 \\
\hline
\end{tabular}

Derivatives Dealer

\begin{tabular}{|ll|ll|}
\hline Assets & & Liabilities & \\
\hline CDS & 0 & CDS & 0 \\
IRS & 0 & IRS & 0 \\
\hline
\end{tabular}


Figure 2a: Value Fluctuation and Credit Expansion

\begin{tabular}{|c|c|c|c|c|c|c|c|}
\hline & \multicolumn{2}{|c|}{ Capital Funding Bank } & \multicolumn{2}{|c|}{ Global Money Dealer } & \multicolumn{3}{|c|}{ Asset Manager } \\
\hline Assets & & Liabilities & Assets & Liabilities & Assets & Liabilities & \\
\hline RMBS & 90 & MM funding 100 & MM funding 100 & "deposits" 100 & "deposits" 100 & Capital & 90 \\
\hline CDS & 10 & & & & & CDS & 10 \\
\hline IRS & 0 & & & & & IRS & 0 \\
\hline
\end{tabular}

\section{Derivatives Dealer}

\begin{tabular}{|ll|ll|}
\hline Assets & & \multicolumn{2}{|l|}{ Liabilities } \\
\hline CDS & 10 & CDS & 10 \\
IRS & 0 & IRS & 0 \\
& & & \\
\hline
\end{tabular}


Figure 2b: Value Fluctuation and Payment

\begin{tabular}{|c|c|c|c|c|c|c|}
\hline & \multicolumn{2}{|c|}{ Capital Funding Bank } & \multicolumn{2}{|c|}{ Global Money Dealer } & \multicolumn{2}{|c|}{ Asset Manager } \\
\hline Asset & & Liabilities & Assets & Liabilities & Assets & Liabilities \\
\hline RMBS & 90 & MM funding 90 & MM funding 90 & \begin{tabular}{|l|} 
"deposits" 90 \\
\end{tabular} & "deposits" 90 & Capital 90 \\
\hline CDS & 0 & & & & & CDS \\
\hline IRS & 0 & & & & & IRS \\
\hline
\end{tabular}

\section{Derivatives Dealer}

\begin{tabular}{|ll|ll|}
\hline Assets & & Liabilities \\
\hline CDS & 0 & CDS & 0 \\
IRS & 0 & IRS & 0 \\
\hline
\end{tabular}


Figure 3: The Past and Future Fed (trillions)

July 4, 2007

December 15, 2011

Dec. 15, 2011, restated

\begin{tabular}{|c|c|c|c|c|c|c|c|c|c|}
\hline \multicolumn{2}{|l|}{ Assets } & \multicolumn{2}{|l|}{ Liabilities } & \multicolumn{2}{|l|}{ Assets } & \multicolumn{2}{|l|}{ Liabilities } & Assets & Liabilities \\
\hline Treasuries & $\$ .79$ & Currency & .82 & Treasuries & $\$ 1.7$ & Currency & 1.0 & [Treasury bills 2.6 & Curr./Reserves 2.6] \\
\hline Other & .12 & Reserves & .01 & MBS \& GSE & .9 & Reserves & 1.6 & [Treasury bonds 2.6 & Treasury bills 2.6] \\
\hline & & Other & .08 & Other & .3 & Other & .3 & $\begin{array}{l}\text { [Risky securities } .9 \\
\text { Other } .3\end{array}$ & $\begin{array}{l}\text { Treasury bonds } .9] \\
\text { Other } .3\end{array}$ \\
\hline TOTAL & .91 & TOTAL & .91 & TOTAL & 2.9 & TOTAL & 2.9 & & \\
\hline
\end{tabular}




\section{References}

Bagehot, Walter. 1906 [1873]. Lombard Street: A Description of the Money Market. New York: Charles Scribner's Sons.

Bank for International Settlements. 2008. “Credit Risk Transfers: Developments from 2005 to 2007." Basel Committee on Banking Supervision.

Bindseil, Ulrich. 2005. Monetary Policy Implementation: Theory, Past, and Present. New York: Oxford University Press.

Brunnermeier, Markus. 2009. “Deciphering the Liquidity and Credit Crunch, 2007-2008." Journal of Economic Perspectives 23(1): 77-100.

Brunnermeier, Markus and Lasse H. Pedersen. 2009. "Market Liquidity and Funding Liquidity." Review of Financial Studies 22(6), 2201-2233.

Ferguson, Thomas and Robert Johnson. 2009. "Too Big to Bail." Part I and II. International Journal of Political Economy 38, No. 1 (Spring) and No. 2 (Summer).

FCIC [Financial Crisis Inquiry Commission]. 2011. The Financial Crisis Inquiry Report. (January) Washington, DC: Government Printing Office.

FOMC [Federal Open Market Committee, Federal Reserve System]. 1952. "Federal Open Market Committee Report of Ad Hoc Subcommittee on the Government Securities Market." Reprinted in The Federal Reserve System after Fifty Years: Hearings before the Subcommittee on Domestic finance of the Committee on Banking and Currency, Vol. 3. $88^{\text {th }}$ Congress, $2^{\text {nd }}$ Session. Washington, DC: U.S. Government Printing Office, 1964.

Gorton, Gary. 2010. Slapped by the Invisible Hand: The Panic of 2007. Financial Management Association Survey and Synthesis. New York: Oxford University Press.

Gorton, Gary and Andrew Metrick. 2010. "Regulating the Shadow Banking System." Brookings Papers on Economic Activity (Fall): 261-312. 
Harris, Larry. 2003. Trading and Exchanges: Market Microstructure for Practitioners. New York: Oxford University Press.

Hicks, John R. 1989. A Market Theory of Money. Oxford: Clarendon Press.

Krishnamurthy, Arvind. 2010. "How Debt Markets Have Malfunctioned in the Crisis." Journal of Economic Perspectives 24(1): 3-28.

Madhavan, Ananth. 2000. "Market Microstructure: A Survey." Journal of Financial Markets 3: 205-258. McGuire, Patrick and Goetz von Peter. 2009. "The U.S. dollar shortage in global banking." BIS Quarterly Review (March): 47-63.

Mehrling, Perry. 2010. "Monetary Implementation Policy: A Microstructure Approach." In David Laidler's Contributions to Macroeconomics, edited by Robert Leeson. London: Palgrave Macmillan.

Mehrling, Perry. 2011. The New Lombard Street, How the Fed Became the Dealer of Last Resort. Princeton, NJ: Princeton University Press.

Moulton, Harold G. 1918. "Commercial Banking and Capital Formation." Journal of Political Economy $26(5,6,7,9): 484-508,638-663,705-731,849-881$.

O'Hara, Maureen. 1995. Market Microstructure Theory. Oxford: Blackwell.

Pozsar, Zoltan. 2011. "Institutional Cash Pools and the Triffin Dilemma of the U.S. Banking System." IMF Working Paper \#190.

Pozsar, Zoltan, Tobian Adrian, Adam Ashcraft, and Hayley Boesky. 2010. "Shadow Banking." Federal Reserve Bank of New York Staff Reports, no. 458.

Shaw, Edward Stone. 1950. Money, Income, and Monetary Policy. Chicago: Irwin.

Shin, Hyung Song and Kwanho Shin. 2011. "Procyclicality and Monetary Aggregates." NBER Working Paper No. 16836. 
SIGTARP [Special Inspector General for the Troubled Asset Relief Program]. 2009. Factors Affecting Efforts to Limit Payments to AIG Counterparties. Washington, DC: Government Printing Office.

Singh, Manmohan and James Aitken. 2010. "The (Sizeable) Role of Rehypothecation in the Shadow Banking System." IMF Working Paper \#172.

Stigum, Marcia and Anthony Crescenzi. 2007. Stigum's Money Market. $4^{\text {th }}$ Edition. New York: McGraw Hill.

Swagel, Phillip. 2009. "The Financial Crisis: An Inside View." Brookings Papers on Economic Activity (Spring), 1-78.

Treynor, Jack. 1987. "The Economics of the Dealer Function." Financial Analysts Journal 43 (6): 27-34. 